\title{
Sutherland Simpson, M.D., D.Sc.
}

Professor Sutherland Simpson, who died at his home on Cajuga Heights, Ithaca, N.Y., U.S.A., on 3rd March 1926, at the age of sixty-three, had occupied for eighteen years the Chair of Physiology at the Medical School of Cornell University, Ithaca, and was head of the conjoint departments of Physiology and Biochemistry.

He was elected a Fellow of this Society in 1911, and has contributed important papers both to its Proceedings and Transactions.

$\mathrm{He}$ was born on the small island of Flotta, in the Orkneys, on 3rd February 1863. As a boy his ambition was to go to sea and eventually to become a merchant captain. With this end in view he directed his attention mainly to mathematics, but he had also an excellent general training in Latin, French, and History. Indeed, it was his knowledge of History which first attracted the attention of the late Professor Rutherford, who appointed him chief laboratory attendant (steward) in 1883. During the eight years he occupied this post he was chiefly engaged in the preparation of experiments for the illustration of the Professor's lectures and of material for the practical classes, but he also found time to attend classes in the Heriot-Watt College, and was able, while still carrying out his laboratory duties, to take the B.Sc. degree in Edinburgh University.

In 1891 he gave up his work in the laboratory in order to qualify in Medicine, eventually taking the M.D. degree. For his thesis presented for this degree he was awarded a gold medal. Later he added the D.Sc. degree to his other academic distinctions. He had just finished his medical course when Professor Schafer was appointed (1899) to succeed Rutherford. Having been made acquainted with the exceptional training and abilities of Simpson, the new professor invited him to become one of his assistants; and three years afterwards he had the title of Lecturer in Experimental Physiology conferred on him.

His work as Assistant and Lecturer was to him extremely interesting; the fruits of his activity in research are to be seen in the series of investigations which he was engaged in during that period, partly with the co-operation of other workers in the Department, especially $P$. T. Herring, J. J. Galbraith, W. A. Jolly, and F. H. A. Marshall. These investigations dealt with the cortico-spinal tracts, the regulation of temperature, the structure of the liver, the secretion pressures of the 
bile and pancreatic juice, and certain of the endocrine organs. In 1908 he was invited to fill the re-constituted Chair of Physiology in Cornell University at Ithaca. He was accompanied by Dr Andrew Hunter, who was associated with him as Lecturer on Biochemistry, and is now Professor of that subject in Toronto University. In Cornell, Simpson organised a most efficient laboratory, equipped with a view not only to the instruction of undergraduates in the practical branches of physiology but also to the prosecution of physiological investigation by graduates. He gathered around him a band of keen and devoted disciples along with whom he continued to pursue researches on the same subjects as had interested him in Edinburgh: attention being given during recent years mainly to the effects of thyroidectomy and parathyroidectomy in herbivora (sheep and goats), for the keeping of which the conditions at Ithaca were especially favourable. Simpson's mastery of operative technique, painstaking care, and powers of observation lend a high value to his work. During the Cornell period he published more than fifty papers; others were contributed by workers in his Department. Several of his students and fellow-workers now occupy important academic positions in America.

In 1919 he was designated as "Memorial Professor in Physiology," one of eight professorships established to commemorate the part played by Cornell in the world war.

Simpson was twice married. By his first wife he had a son and daughter: both are graduates of Cornell, and the son is M.D. of Harvard as well. His second wife survives him.

Of a modest and lovable nature, Simpson's character was distinguished by a quite unusual degree of homesty and loyalty-qualities which endeared him to his friends and students and commanded the respect of all who came in contact with him. He will be greatly missed not only by those who knew him personally but by many who were only acquainted with him through his published works.

T. H. M. 